\title{
ANALISIS VARIABEL PEMBANGUNAN EKONOMI DAN SOSIAL DAERAH PROVINSI SUMATERA SELATAN PERIODE 1980-2013 (SEBUAH KAJIAN DENGAN PENDEKATAN ECM DAN VECM)
}

\author{
Abdul Hamid \\ FEB UIN Syarif Hidayatullah Jakarta \\ abdul.hamid@uinjkt.ac.id
}

\begin{abstract}
ABSTRAK
Tujuan penelitian ini adalah untuk menganalisis bubungan keseimbangan antar variable pembangunan ekonomi dan sosial daerah dengan menggunakan metode vector dan error correction model dan menganalisi kointegrasi serta kausalitas antar variabel dengan menggunakan metode cointegration dan causality. Metode yang digunakan ialah Error Correction Model (ECM) dan Vektor Error Correction Model (VECM). Variabel penelitian ini terdiri dari inflasi, Indeks Harga Konsumen (IHK), dan Produk Domestik. Regional Bruto (PDRB) yang mewakili variabel pembangunan ekonomi serta, variabel pembangunan sosial diwakili oleh Indeks Pembangunan manusia (IPM), Kemiskinan dan Pengangguran. Penelitian ini akan menggunakan uji root dengan menggunakan metode Augmented Dickey Fuller test (ADF-test). Hasil penelitian ini menunjukkan bahwa terdapat pengaruh yang signifikan antara variabel inflasi dan Produk Domestik. Regional Bruto (PDRB) di Provinsi Sumatera Selatan dalam jangka panjang dan jangka pendek. Sementara itu, variabel independen lainnya (IHK, IPM, Kemiskinan dan Pengangguran) dalam jangka pendek maupun jangka panjang secara simultan berpengaruh pada PDRB. Terdapat bubungan keseimbangan Antar variable pembangunan ekonomi (PDRB, Inflasi, IHK) dan variabel sosial (IPM, Kemiskinan dan Pengangguran) di Provinsi Sumatera Selatan dengan menggunakan metode vector dan error correction model dan antar variable pembangunan ekonomi dan sosial berkointegrasi dan berkausalitas dengan menggunakan metode cointegration dan causality.
\end{abstract}

Kata kunci: indikator pembangunan ekonomi, sosial, VECM, ECM

\section{PENDAHULUAN}

Era otonomi dalam pembangunan nasional Indonesia telah berjalan dengan cukup baik. Dalam hal pelaksanaan undang-undang Nomor 32 Tahun 2004 tentang Pemerintahan daerah, masih banyak mengalami hambatan. Hal ini disebabkan karena setiap daerah memiliki sumber daya dan kemampuan yang berbeda-beda, sehingga penerapan konsep otonomi ini menimbulkan kesenjangan antar daerah yang relatif tinggi. Otonomi daerah diharapkan dapat mendorong pembangunan di daerah lebih cepat dengan adanya otonomi dalam hal pengelolaan sektor-sektor pembangunan termasuk pengelolaan keuangannya. Namun pada kenyataannya hal ini juga menimbulkan dampak lain diantaranya maraknya korupsi di daerah. Pasal 1 butir 5 UU Nomor 32 Tahun 2004 dinyatakan bahwa Otonomi daerah adalah hak, wewenang, dan 
kewajiban daerah otonom untuk mengatur dan mengurus sendiri urusan pemerintahan dan kepentingan masyarakat setempat sesuai dengan peraturan perundang-undangan. Hal ini mengindikasikan bahwa daerah memiliki kewenangan mengurusi berbagai aspek pembangunan termasuk masalah pembangunan ekonomi dan sosial.

Sumatera Selatan adalah salah satu provinsi di Indonesia yang memiliki tingkat pertumbuhan ekonomi cukup baik saaat ini. Wilayah Propinsi Sumatera Selatan mencakup areal seluas 109.254 kilometer persegi. Pembangunan di provinsi ini juga mengalami banyak hambatan. Berbagai hambatan pembangunan ini juga dihadapi dalam pembangunan ekonomi dan sosial. Namun demikian, pembangunan kedua sektor ini dinilai cukup berhasil hal ini dapat dilihat dari indikator kinerja pembangunan ekonomi dan sosialnya. Secara konsisten, Pemerintah Provinsi Sumatera Selatan menuangkan upayanya untuk mencapai tujuan pembangunan daerah ke dalam perencanaan, strategi dan berbagai program pembangunan yang dikristalisasikan ke dalam 3 (tiga) hal pokok, yaitu Reorientasi, Reposisi, dan Revitalisasi (Bappeda Sumsel, 2013). Reorientasi, ditujukan untuk mengubah dari pertumbuhan ekonomi menjadi perbaikan ekonomi termasuk atau sekaligus pemerataan. Reposisi, dimaksudkan sebagai perubahan peran pemerintah provinsi dari pelaksana menjadi perencana, pelaksana dan pembiayaan pembangunan sekaligus. Perubahan peran tersebut mengharuskan perbedaan pola kerja pimpinan puncak Pemerintah Provinsi dari mengatur ke dalam (inward looking) menjadi mencari ke luar (outward looking). Revitalisasi, dimaksudkan untuk menguatkan kembali perencanaan jangka panjang dan lembaga perencanan. Dalam satu daerah hanya ada satu rencana pembangunan induk yang menjadi acuan semua pihak terkait dan bertanggung jawab dalam pelaksanaan dan pembiayaan. Hal ini memungkinkan terjadinya keterpaduan dalam pelaksanaan pembangunan, sehingga lebih efektif, efisien dan profesional.

Berbagai prestasi pembangunan daerah yang telah diraih, baik oleh Pemerintah Provinsi maupun Kabupaten/Kota. Pengakuan Pemerintah pusat dan dari berbagai pihak dalam dan luar negeri mendanai keberhasilan yang dicapai sebagai dampak positif upaya perubahan yang dilangsungkan dalam kurun waktu hampir 5 tahun ini. Pengakuan tersebut meliputi antar lain bidang pendidikan, kesehatan, perencanaan pembangunan, pengelolaan keuangan daerah, litbang, investasi, pertanian tanaman pangan, perkebunan, kehutanan, transmigrasi, perumahan rakyat, energi dan sumber daya mineral, olahraga, dan penanggulangan bencana.

Pembangunan ekonomi hingga Triwulan kedua Tahun 2013 di Provinsi Sumatera Selatan sedikit melambat dibandingkan kinerja triwulan sebelumnya dari 6,2\% (yoy) menjadi 6,1\% (yoy) (Bank Indonesia, 2013). Demikaina pula dengan PDRB Sumatera Selatan secara triwulanan pada triwulan II 2013 tumbuh 4,1\% (qtq). Kondisi tersebut terutama diakibatkan oleh perlambatan pertumbuhan sektor industri pengolahan dan sektor perdagangan, hotel dan restoran. Seiring dengan itu, terdapat perlambatan ekspor dan konsumsi pemerintah. Dari sisi harga, terjadi 
penurunan inflasi cukup signifikan yang terutama disebabkan adanya relaksasi pembatasan impor hortikultura dan penurunan risiko produksi dan distribusi. Perbankan menunjukkan perlambatan pertumbuhan aktivitas namun dengan tetap mengendalikan risiko kredit dengan baik. Sementara itu, pemerintah daerah berperan ekspansif pada perekonomian dengan merealisasikan belanja lebih cepat dari biasanya, khususnya untuk kegiatan investasi. Kondisi kesejahteraan masyarakat relative tidak mengalami banyak perubahan.

Dalam hal pembangunan sosial, Provinsi Sumatera Selaan mencatat prestasi yang cukup baik. Indikator pembangunan sosial diantaranya ialah tingkat pengangguran, kemiskinan dan Indeks Pembangunan Manusia. Pengangguran merupakan indikator utama dari bidang ketenagakerjaan dan kesejahteraan. Klasifikasi penduduk yang menganggur adalah penduduk yang sedang mencari pekerjaan ditambah penduduk yang sedang mempersiapkan usaha (tidak bekerja), yang mendapat pekerjaan tetapi belum mulai bekerja, serta yang tidak mungkin mendapatkan pekerjaan (BI, 2013). Cukup baiknya kondisi perekonomian secara umum di Sumatera Selatan menyebabkan angka pengangguran tahun 2013 cukup rendah, dan lebih rendah dibandingkan posisi tahun 2012. Berdasarkan data BPS Sumsel, Tingkat Pengangguran Terbuka (TPT) di Sumsel pada bulan Februari 2013 sebesar 5,49\%, lebih rendah dibandingkan kondisi pada bulan Februari 2012 yang sebesar 5,59\%, dan lebih rendah dibandingkan posisi periode semester sebelumnya yang sebesar $5,70 \%$.

Menurut data BPS Sumsel 2013, tingkat kemiskinan hingga tahun 2013 juga terus mengalami penurunan. Jumlah penduduk miskin pada bulan September 2013 yang berjumlah 1.104.569 orang (14,06 persen), berarti jumlah penduduk miskin turun sebanyak 3.740 orang atau 0,15\%. Selama periode September 2013 - Maret 2014, penduduk miskin di daerah perkotaan turun sebanyak 7.607 orang, atau sebesar 0,35 persen. Di daerah perdesaan juga mengalami penurunan sebanyak 3.867 orang, atau sebesar 0,04 persen. Komposisi penduduk miskin menurut daerah tempat tinggal (perkotaan dan perdesaan) tidak banyak berubah, di mana sebagian besar (66,65 persen) penduduk miskin berada di daerah perdesaan. Besar kecilnya jumlah penduduk miskin sangat dipengaruhi oleh Garis Kemiskinan, karena penduduk miskin adalah penduduk yang memiliki rata-rata pengeluaran per kapita per bulan dibawah Garis Kemiskinan (BPS SUMSEL, 2012).

Sementara itu pada sisi lain, Indeks Pembangunan Manusia (IPM) Sumatera Selatan juga terus mengalami peningkatan. Data BPS Sumatera Selatan Tahun 2007-2011 menunjukkan besarnya IPM berturut-turut sebesar 71,40 (2007), 72,05 (2008), 72,61 (2009), 72,95 (2010), dan 73,42 (2011). Sehingga dari sisi pembangunan manusia masih perlu peningkatan dibidang pendidikan, kesejahteraan dan pemerataan.

Secara umum, kinerja pembangunan daerah provinsi Sumatera Selatan dapat dilihat dari indikator ekonomi makro daerah dalam tabel berikut 
Tabel 1.

INDIKATOR DAN CAPAIAN KINERJA PEMBANGUNAN MAKRO DAERAH PROVINSI SUMATERA SELATAN TAHUN 2009 - 2013

\begin{tabular}{|c|c|c|c|c|c|c|c|c|c|c|c|}
\hline \multirow{2}{*}{$\begin{array}{l}\text { Indikator } \\
\text { Kinerja }\end{array}$} & \multirow[b]{2}{*}{ satuan } & \multicolumn{2}{|c|}{2009} & \multicolumn{2}{|c|}{2010} & \multicolumn{2}{|c|}{2011} & \multicolumn{2}{|c|}{2012} & \multicolumn{2}{|c|}{2013} \\
\hline & & target & $\begin{array}{c}\text { realisa } \\
\text { si }\end{array}$ & $\begin{array}{c}\operatorname{targ} \\
\text { et }\end{array}$ & $\begin{array}{c}\text { realis } \\
\text { asi }\end{array}$ & target & $\begin{array}{l}\text { realis } \\
\text { ai }\end{array}$ & target & $\begin{array}{l}\text { realis } \\
\text { asi }\end{array}$ & target & $\begin{array}{l}\text { realisa } \\
\text { si }\end{array}$ \\
\hline $\begin{array}{l}\text { Pertumbuhan } \\
\text { ekonomi }\end{array}$ & $\%$ & 4,3 & 4,1 & 5,2 & 5,6 & 5,7 & 6,5 & 6,7 & 6 & 6,9 & na \\
\hline $\begin{array}{l}\text { Pendapatan per } \\
\text { kapita Harga } \\
\text { berlaku dg migas }\end{array}$ & Rp.000 & 13.676 & 16.140 & 13.866 & 17.990 & 14.052 & 20.330 & 14.237 & 26.615 & 14.419 & \\
\hline Inflasi & $\%$ & 8 & 1,85 & 7,8 & 6,02 & 7,2 & 3,78 & 7,3 & 3,87 & 7,4 & na \\
\hline $\begin{array}{l}\text { Pendapatan } \\
\text { Daerah }\end{array}$ & Rp. M & $2.818,82$ & 2.397 & $3.037,72$ & 3.211 & $3.274,79$ & $3.759,60$ & $3.548,49$ & $5.028,74$ & $3.864,57$ & $5.768,32$ \\
\hline $\begin{array}{l}\text { Pendapatan Asli } \\
\text { Daerah }\end{array}$ & Rp. M & $1.082,71$ & $1.054,32$ & $1.263,04$ & $1.363,16$ & $1.456,35$ & $1.686,95$ & $1.681,61$ & $1.907,70$ & $1.944,38$ & $2.287,02$ \\
\hline $\begin{array}{l}\text { Dana } \\
\text { Perimbangan }\end{array}$ & Rp. M & $1.726,67$ & $1.333,17$ & $1.765,06$ & $1.797,29$ & $1.808,62$ & $1.988,94$ & $1.856,54$ & $2.240,01$ & $1.909,23$ & $2.264,84$ \\
\hline $\begin{array}{l}\text { Lain lain } \\
\text { Pendapatan yang } \\
\text { sah }\end{array}$ & Rp. M & 9,44 & 9,42 & 9,62 & 50,26 & 9,81 & 83,713 & 10,34 & 881,02 & 10,96 & 836,46 \\
\hline $\begin{array}{l}\text { Jumlah } \\
\text { Penduduk }\end{array}$ & ribu & $7.222,60$ & $7.329,78$ & $7.322,50$ & $7.450,39$ & $7.421,20$ & $7.593,43$ & $7.518,70$ & $7.752,84$ & $7.614,90$ & na \\
\hline $\begin{array}{l}\text { Laju } \\
\text { Pertumbuhan } \\
\text { Penduduk } \\
\end{array}$ & $\%$ & 1,38 & 1,81 & 1,35 & 1,8 & 1,31 & 1,77 & 1,28 & 1,74 & 1,24 & na \\
\hline $\begin{array}{l}\text { Jumlah } \\
\text { Penduduk } \\
\text { Miskin } \\
\end{array}$ & ribu jiwa & 1.339 & 1.167 & 1.337 & 1.125 & 1.335 & 1.074 & 1.109 & 1.057 & 1.066 & na \\
\hline $\begin{array}{l}\text { \% Penduduk } \\
\text { Miskin }\end{array}$ & $\%$ & 16,98 & 16,28 & 16,24 & 15,47 & 15,49 & 14,24 & 14,75 & 13,78 & 14 & $\mathrm{Na}$ \\
\hline $\begin{array}{l}\text { Tingkat } \\
\text { Pengangguran } \\
\text { Terbuka }\end{array}$ & $\%$ & 7,86 & 7,61 & 7,65 & 6,65 & 7,43 & 5,77 & 7,22 & 5,7 & 7 & $\mathrm{Na}$ \\
\hline
\end{tabular}

Sumber: BPS, 2013

\section{Pertumbuhan ekonomi}

Pertumbuhan ekonomi dapat diartikan juga sebagai proses kenaikan kapasitas produksi suatu perekonomian yang diwujudkan dalam bentuk kenaikan pendapatan nasional. Menurut Sadono Sukirno (1996: 33), pertumbuhan dan pembangunan ekonomi memiliki definisi yang berbeda, yaitu pertumbuhan ekonomi ialah proses kenaikan output perkapita yang terus menerus dalam jangka panjang. Pertumbuhan ekonomi tersebut merupakan salah satu indikator keberhasilan pembangunan. Dengan demikian makin tingginya pertumbuhan ekonomi biasanya makin tinggi pula kesejahteraan masyarakat, meskipun terdapat indikator yang lain yaitu distribusi pendapatan. Simon Kuznet mendefenisikan pertumbuhan ekonomi suatu negara sebagai "kemampuan negara itu untuk menyediakan barang-barang ekonomi yang terus meningkat bagi penduduknya, pertumbuhan kemampuan ini berdasarkan pada kemajuan teknologi dan kelembagaan serta penyesuaian ideologi yang dibutuhkannya". Indikator yang digunakan untuk menghitung tingkat Pertumbuhan Ekonomi yaitu Tingkat Pertumbuhan PDB 
(Produk Domestik Bruto) dan Tingkat Pertumbuhan PNB (Produk Nasional Bruto), untuk di daerah digunakan PDRB.

\section{Inflasi}

Inflasi adalah proses kenaikan harga-harga umum secara terus-menerus selama periode tertentu. (Nopirin, 1990: 25). Inflasi terjadi apabila tingkat harga-harga dan biaya-biaya umum naik, harga beras, bahan bakar, harga mobil naik, tingkat upah, harga tanah, dan semua barangbarang modal naik. (Samuelson dan Nordhaus, 1993: 293). Berdasarkan definisi tersebut dapat disimpulkan pengertian inflasi adalah proses kenaikan harga barang-barang secara umum dan terus-menerus disebabkan oleh turunnya nilai uang pada suatu periode tertentu. Ini tidak berarti bahwa harga-harga barang naik dengan persentase yang sama.

\section{Indek Harga Konsumen (IHK)}

Inflasi menggambarkan situasi saat tingkat harga perekonomian secara keseluruhan meningkat. Laju inflasi adalah perubahan persentase pada tingkat harga dari periode sebelumnya. Indeks harga konsumen (IHK - consumer price indeks [CPI]) adalah ukuran biaya keseluruhan barang dan jasa yang dibeli oleh konsumen. Ahli statistik pemerintah secara rutin (biasanya setiap bulan) menghitung dan melaporkan indeks harga konsumen. Laporan indeks harga konsumen ini digunakan untuk memonitor perubahan biaya hidup dari waktu ke waktu. IHK mengukur harga sekumpulan barang tertentu (seperti bahan makanan pokok, sandang, perumahan, dan aneka barang dan jasa) yang dibeli konsumen. Indeks harga Konsumen (IHK) merupakan persentase yang digunakan untuk menganalisis tingkat/ laju inflasi. IHK juga merupakan indikator yang digunakan pemerintah untuk mengukur inflasi di Indonesia. Di Indonesia badan yang bertugas untuk menghitung Indeks Harga Konsumen (IHK) adalah Badan Pusat Statistik (BPS). Penghitungan IHK dimulai dengan mengumpulkan harga dari tibuan barang dan jasa. Jika PDB mengubah jumlah berbagai barang dan jasa menjadi sebuah angka tunggal yang mengukur nilai produksi, IHK mengubah berbagai harga barang dan jasa menjadi sebuah indeks tunggal yang mengukur seluruh tingkat harga. Badan Pusat Statistik menimbang jenis-jenis produk berbeda dengan menghitung harga sekelompok barang dan jasa yang dibeli oleh konsumen tertentu. IHK adalah harga sekelompok barang dan jasa relatif terhadap harga sekelompok barang dan jasa yang sama pada tahun dasar. IHK adalah indeks yang sering dipakai namun bukanlah satu-satunya indeks yang dipakai untuk mengukur laju inflasi. Masih ada indeks yang dapat digunakan yakni indeks Harga Produsen (IHP), yang mengukur harga sekelompok barang yang dibeli perusahaan (produsen bukannya konsumen). 


\section{Indeks Pembangunan Manusia (IPM)}

UNDP (United Nation Development Programme) mendefenisikan pembangunan manusia sebagai suatu proses untuk memperluas pilihan-pilihan bagi penduduk. Dalam konsep tersebut penduduk ditempatkan sebagai tujuan akhir (the ultimated end) sedangkan upaya pembangunan dipandang sebagai sarana (principal means) untuk mencapai tujuan itu. Untuk menjamin tercapainya tujuan pembangunan manusia, empat hal pokok yang perlu diperhatikan adalah produktivitas, pemerataan, kesinambungan, pemberdayaan (UNDP, 1995).

\section{Kemiskinan}

Definisi menurut UNDP dalam Cahyat (2004), adalah ketidakmampuan untuk memperluas pilihan-pilihan hidup, antara lain dengan memasukkan penilaian tidak adanya partisipasi dalam pengambilan kebijakan publik sebagai salah satu indikator kemiskinan. Menurut Soerjono Soekanto Kemiskinan diartikan sebagai suatu keadaan dimana seseorang tidak sanggup memelihara dirinya sendiri sesuai dengan taraf kehidupan kelompok dan juga tidak mampu memanfaatkan tenaga mental, maupun fisiknya dalam kelompok tersebut. UNDP selain mengukur kemiskinan dengan parameter pendapatan pada tahun 1997 memperkenalkan apa yang disebut Indeks Kemiskinan Manusia (IKM) (Human Poverty Indeks-HPI) atau biasa juga disebut Indeks Pembangunan Manusia (Human Development Indeks-HDI), yakni bahwa kemiskinan harus diukur dalam satuan hilangnya tiga hal utama (theree key deprivations), yaitu kehidupan, pendidikan dan ketetapan ekonomi.

\section{Pengangguran}

Nanga (2005: 249) mendefinisikan pengangguran adalah suatu keadaan di mana seseorang yang tergolong dalam kategori angkatan kerja tidak memiliki pekerjaan dan secara aktif tidak sedang mencari pekerjaan. Dalam sensus penduduk 2001 mendefinisikan pengangguran sebagai orang yang tidak bekerja sama sekali atau bekerja kurang dari dua hari selama seminggu sebelum pencacahan dan berusaha memperoleh pekerjaan (BPS, 2001: 8). Menurut Sukirno (2004: 28) pengangguran adalah jumlah tenaga kerja dalam perekonomian yang secara aktif mencari pekerjaan tetapi belum memperolehnya. Selanjutnya International Labor Organization (ILO) memberikan definisi pengangguran yaitu:

a) Pengangguran terbuka adalah seseorang yang termasuk kelompok penduduk usia kerja yang selama periode tertentu tidak bekerja, dan bersedia menerima pekerjaan, serta sedang mencari pekerjaan.

b) Setengah pengangguran terpaksa adalah seseorang yang bekerja sebagai buruh karyawan dan pekerja mandiri (berusaha sendiri) yang selama periode tertentu secara terpaksa bekerja kurang dari jam kerja normal, yang masih mencari pekerjaan lain atau masih bersedia mencari pekerjaan lain/tambahan (BPS, 2001: 4). 
Dari latar belakang diatas, masalah dalam penelitian ini dirumuskan sebagai berikut: (1) Apakah terdapat hubungan keseimbangan antar variable pembangunan ekonomi dan sosial daerah dengan menggunakan metode vector dan error correction model dan (2) Apakah antar variable pembangunan ekonomi dan sosial daerah berkointegrasi dan berkausalitas dengan menggunakan metode cointegration dan causality antar variable. Variabel yang digunakan dalam peneltian ini yaitu PDRB. Laju inflasi, Indek Harga Konsumen (IHK), IPM, Kemiskinan dan Pengangguran.

\section{METODOLOGI}

Data yang digunakan sebagai objek penelitian dalam penelitian ini adalah data variable pembangunan ekonomi dan sosial yang sebagian besar dari data tersebut didapat dari BPS dan terlebih dahulu diolah oleh penulis. Data yang digunakan menggunakan tahun dasar 2006 dan tahun akhir 2013. Setelah semua data didapat, lalu diolah dengan menggunakan software e-views 7.2 yang dapat mengolah model ECM dan VECM. Penelitian ini berbentuk kausal dengan dimensi waktu penelitian adalah tahun 1993-2013 untuk data variable pembangunan ekonomi dan sosial di Sumatera Selatan.

Data penelitian sebelum digunakan untuk estimasi perlu dilakukan serangkaian tahapan pengujian, yaitu: uji stationary, uji Granger causality, Kemudian setelah itu, untuk mengkaji data timeseries yang dipergunakan sebagai berikut:

\section{a. Uji Akar-Akar Unit (Unit Root Tests)}

Dalam statistik dan ekonometrik, uji akar unit digunakan untuk menguji adanya anggapan bahwa sebuah data time series tidak stasioner. Uji yang biasa digunakan adalah uji Augmented Dickey Fuller test (ADF-test). Uji lain yang serupa yaitu Uji Pbillips-Perron (PP-Test). Keduanya mengindikasikan keberadaan akar unit sebagai hipotesis null. Data yang dikatakan stasioner adalah data yang bersifat flat, tidak mengandung komponen trend, dengan keragaman yang konstan, serta tidak terdapat fluktuasi periodik. Apabila koefisien Yt-1 (@) adalah $=1$ yang artinya hipotesis diterima, maka variabel mengandung unit root dan bersifat non-stasioner. Untuk mengubah trend yang bersifat non-stasioner menjadi stasioner dilakukan uji orde pertama (first difference): $\Delta \mathrm{Yt}=\left(\mathrm{Q}^{-1}\right)$ (Yt - Yt-1. Koefisien $\varrho$ akan bernilai 0, dan hipotesis akan ditolak sehingga model menjadi stasioner. Hipotesis yang digunakan pada pengujian ADF adalah:

$\mathrm{H} 0: \varrho=0$ (Terdapat unit roots, variabel $\mathrm{Y}$ tidak stasioner)

$\mathrm{H} 1: \varrho \neq 0$ (Tidak terdapat unit roots, variabel Y stasioner)

Kesimpulan hasil root test diperoleh dengan membandingkan nilai t-hitung dengan ttabel pada tabel Dickey-Fuller. 


\section{b. Uji Kointegrasi Johannsen (Johansen Cointergration Test)}

Kombinasi dari dua seri yang tidak stasioner, akan bergerak kearah yang sama menuju ekuilibrium jangka panjangnya dan diferensiasi diantara kedua seri tersebut akan konstan. Jika demikian maka data time series ini dikatakan saling kointegrasi

\section{c. Uji Kausalitas Granger (Granger Causality)}

Uji Granger Causality dimaksudkan untuk melihat pengaruh masing-masing variable terhadap variable lainnya satu per satu. Dengan didasarkan pada hipotesis kausalitas Granger.

\section{d. Model Empiris ECM dan VECM}

Adanya masalah tersebut mendorong alternatif lain yang sering disebut model non-structural. Pendekatan ini mencari hubungan antara bermacam-macam variabel yang diinginkan. Model tersebut sering disebut VAR maupun ECM dan VECM yang umumnya digunakan untuk peramalan dari hubungan data time series.

\section{HASIL DAN PEMBAHASAN}

Hasil Uji Stationary

Pada dasarnya korelogram merupakan teknik identifikasi kestationeran data time series melalui fungsi Autokorelasi (ACF). Fungsi ini bermanfaat untuk menjelaskan suatu proses stokastik, dan akan memberikan informasi bagaimana korelasi antara data $(\mathrm{Yt})$ yang berdekatan.

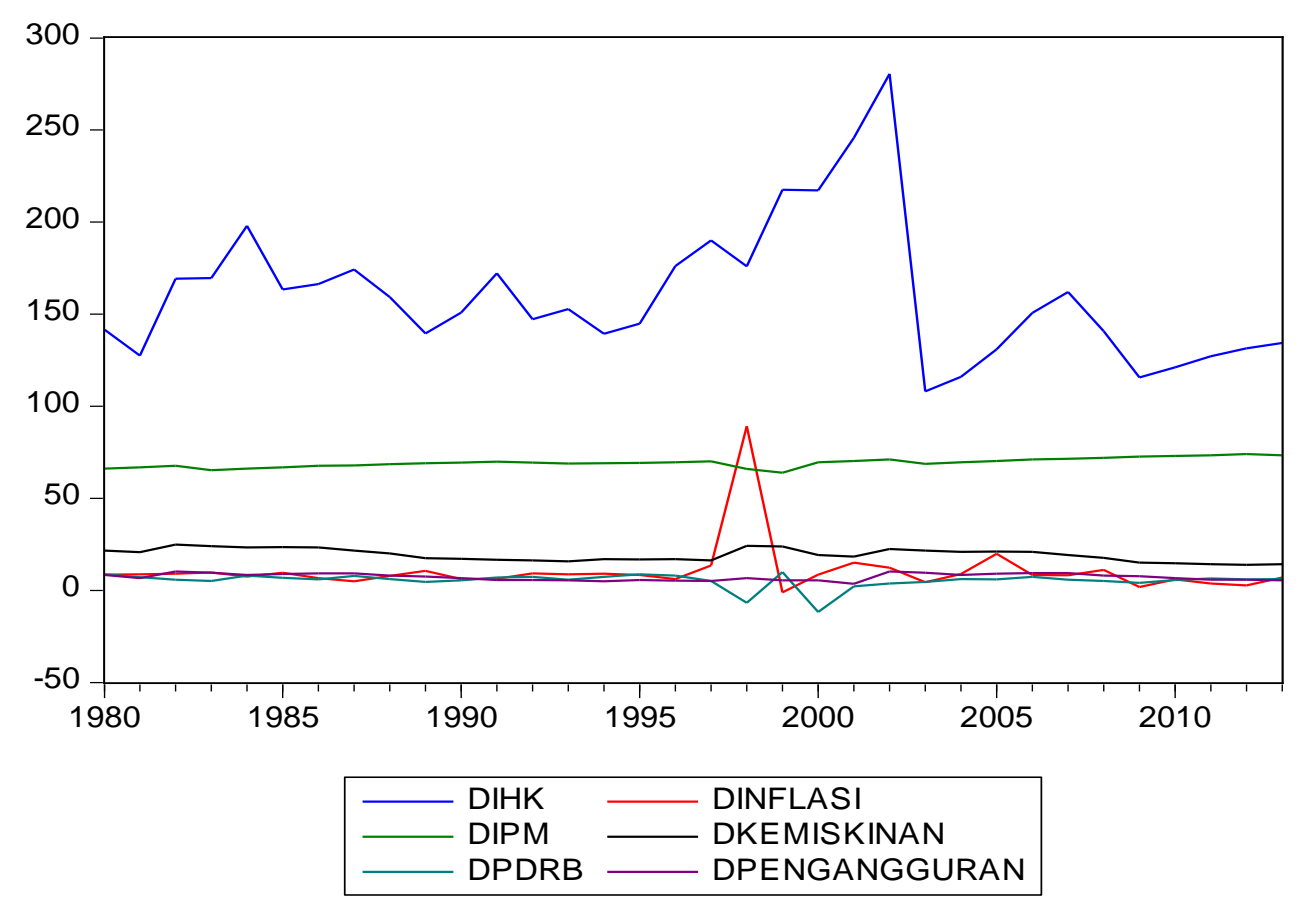

\section{Uji Akar Unit}

Dalam analisis data time series, uji stasioner diketahui dengan menggunakan uji akar unit (unit root) dengan menggunakan metode $A D F$. Terlebih dahulu menguji setiap variabel pada derajat $\mathrm{I}(0)$ atau derajat level. Hasil uji stasioneritas data pada derajat level untuk seluruh variabel 
menunjukkan beberapa variabel tidak stasioner sehingga harus diulang dengan menguji variabel pada derajat first difference (1st difference). Nilai kestasioneritas data dapat juga diketahui dari nilai probabilitas Mac-Kinnon dimana nilai prob. Mac-Kinnon lebih kecil dari nilai probabilitas kritis $\alpha=1 \%, 5 \%$ atau $10 \%$. Hasil uji ini menunjukkan bahwa seluruh variabel stasioner pada diferensiasi pertama (1st difference).

Tabel 2. Hasil uji root test pada derajat 1st difference

\begin{tabular}{|l|c|c|c|c|c|}
\hline \multirow{2}{*}{ Variabel } & ADF t- & \multicolumn{3}{c|}{ Nilai Kritis } & Prob \\
\cline { 4 - 6 } & statistic & $\mathbf{1 \%}$ & $\mathbf{5 \%}$ & $\mathbf{1 0} \mathbf{0}$ & \\
\hline DIHK & -6.570762 & -4.273277 & -3.557759 & -3.212361 & 0.0000 \\
& & & & & \\
\hline DINFLASI & -7.074065 & -4.284580 & -3.562882 & -3.215267 & 0.0000 \\
\hline DIPM & -5.399602 & -4.296729 & -3.568379 & -3.218382 & 0.0007 \\
\hline DKEMISKINAN & -5.459588 & -4.284580 & -3.562882 & -3.215267 & 0.0006 \\
\hline DPDRB & -13.10943 & -4.273277 & -3.557759 & -3.212361 & 0.0000 \\
\hline DPENGANGGURAN & -7.373935 & -4.273277 & -3.557759 & -3.212361 & 0.0000 \\
\hline
\end{tabular}

Seluruh hasil uji pada derajat level menunjukkan data tidak stasioner, maka dilanjutkan dengan uji pada diferensiasi pertama. Hasil Uji Root Test pada derajat 1 st difference sudah menunjukkan bahwa semua data stasioner. Karena seluruh variabel sudah stasioner pada diferensi pertama maka tidak perlu dilanjutkan uji stasioner ke diferensiasi kedua. Dari output yang dihasilkan, terlihat bahwa nilai statistik t seluruh variabel sudah lebih besar daripada nilai $\mathrm{t}$ pada tabel McKinon pada tingkat kepercayaan 1\%, 5\%, maupun 10\%. Serta nilai probabilitasnya lebih kecil dari nilai kritis $0,05(<0,05)$. Dengan demikian data telah stasioner pada diferensiasi tahap pertama (1 st difference) dan hipotesis null dapat ditolak.

Null Hypothesis: D(RESID) has a unit root Exogenous: Constant, Linear Trend Lag Length: 2 (Automatic - based on SIC, maxlag=7)

\begin{tabular}{lccc}
\hline \hline & t-Statistic & Prob.* \\
\hline \hline \multicolumn{2}{l}{ Augmented Dickey-Fuller test statistic } & -5.864366 & 0.0003 \\
\hline Test critical values: & 1\% level & -4.339330 & \\
& $5 \%$ level & -3.587527 & \\
& $10 \%$ level & -3.229230 & \\
\hline \hline
\end{tabular}

*MacKinnon (1996) one-sided p-values. 
Augmented Dickey-Fuller Test Equation

Dependent Variable: D(RESID,2)

Method: Least Squares

Date: 08/07/14 Time: 14:11

Sample (adjusted): 19872013

Included observations: 27 after adjustments

\begin{tabular}{lllll}
\hline \hline Variable & Coefficient & Std. Error & t-Statistic & Prob. \\
\hline \hline D(RESID(-1)) & -2.821151 & 0.481067 & -5.864366 & 0.0000 \\
D(RESID(-1),2) & 1.047755 & 0.360480 & 2.906554 & 0.0082 \\
D(RESID(-2),2) & 0.469868 & 0.188044 & 2.498718 & 0.0204 \\
C & -0.128261 & 1.217854 & -0.105317 & 0.9171 \\
@TREND(1980) & 0.005178 & 0.056745 & 0.091254 & 0.9281 \\
\hline \hline R-squared & 0.821533 & Mean dependent var & 0.030592 \\
Adjusted R-squared & 0.789085 & S.D. dependent var & 4.998649 \\
S.E. of regression & 2.295656 & Akaike info criterion & 4.665490 \\
Sum squared resid & 115.9408 & Schwarz criterion & 4.905460 \\
Log likelihood & -57.98412 & Hannan-Quinn criter. & 4.736846 \\
F-statistic & 25.31804 & Durbin-Watson stat & 1.838319 \\
Prob(F-statistic) & 0.000000 & & & \\
\hline \hline
\end{tabular}

Hasil penelitian menunjukkan bahwa data original dat menunjukkan stationary, karena nilai uji ADF nya lebih kecil dari nilai signifikannya, sehingga dapat dipastikan bahwa pada data mengandung stationeritas. Probabilitas tingkat signifikannya juga menunjukkan angka signifikan pada tingkat $\alpha=5 \%$ pada nilai RESID1(-1).

\section{Uji Panjang Lag (Penentuan Lag Optimal)}

Lag optimal merupakan jumlah lag yang memberikan pengaruh atau respons yang signifikan. Dimana hasil dalam uji panjang lag (Lag Length) ditentukan dengan jumlah bintang terbanyak yang direkomendasi dari masing-masing kriteria uji lag length. Dari hasil pengujian ditemukan bahwa untuk kedua model, lag yang disarankan adalah 1. Sebagaimana prinsip parsimoni (parsimony), asumsi yang digunakan oleh Johansen's cointegration test adalah mencari log likelihood test statistik terkecil atas persamaan ECM maupun VECM. Dari rekapitulasi log likelihood dari persamaan ECM dan VECM mulai lag $1 \mathrm{~s} / \mathrm{d}$ lag 2 untuk periode 1980 sampai 2013. 
Vector Autoregression Estimates

Date: 08/07/14 Time: 14:28

Sample (adjusted): 19822013

Included observations: 32 after adjustments

Standard errors in () \& t-statistics in []

\begin{tabular}{|c|c|c|c|c|c|c|}
\hline & DIHK & DINFLASI & DIPM & $\begin{array}{c}\text { DKEMISKI } \\
\text { NAN }\end{array}$ & DPDRB & $\begin{array}{c}\text { DPENGAN } \\
\text { GGURAN }\end{array}$ \\
\hline $\operatorname{DIHK}(-1)$ & $\begin{array}{c}0.185458 \\
(0.17836) \\
{[1.03977]}\end{array}$ & $\begin{array}{c}0.147673 \\
(0.16344) \\
{[0.90352]}\end{array}$ & $\begin{array}{r}-0.013048 \\
(0.00960) \\
{[-1.35844]}\end{array}$ & $\begin{array}{r}-0.005780 \\
(0.02025) \\
{[-0.28539]}\end{array}$ & $\begin{array}{r}-0.032951 \\
(0.02919) \\
{[-1.12870]}\end{array}$ & $\begin{array}{r}-0.010140 \\
(0.00900) \\
{[-1.12693]}\end{array}$ \\
\hline DIHK(-2) & $\begin{array}{r}-0.422832 \\
(0.14246) \\
{[-2.96798]}\end{array}$ & $\begin{array}{c}0.006340 \\
(0.13055) \\
{[0.04857]}\end{array}$ & $\begin{array}{r}-0.001820 \\
(0.00767) \\
{[-0.23718]}\end{array}$ & $\begin{array}{c}0.000842 \\
(0.01618) \\
{[0.05206]}\end{array}$ & $\begin{array}{r}-0.008421 \\
(0.02332) \\
{[-0.36114]}\end{array}$ & $\begin{array}{c}0.005432 \\
(0.00719) \\
{[0.75581]}\end{array}$ \\
\hline DINFLASI(-1) & $\begin{array}{r}-0.196195 \\
(0.62550) \\
{[-0.31366]}\end{array}$ & $\begin{array}{r}0.075304 \\
(0.57317) \\
{[0.13138]}\end{array}$ & $\begin{array}{r}-0.004971 \\
(0.03368) \\
{[-0.14758]}\end{array}$ & $\begin{array}{c}0.034609 \\
(0.07102) \\
{[0.48730]}\end{array}$ & $\begin{array}{r}0.012683 \\
(0.10238) \\
{[0.12388]}\end{array}$ & $\begin{array}{c}0.040928 \\
(0.03156) \\
{[1.29701]}\end{array}$ \\
\hline DINFLASI(-2) & $\begin{array}{r}-0.988124 \\
(0.37860) \\
{[-2.60995]}\end{array}$ & $\begin{array}{r}-0.166302 \\
(0.34693) \\
{[-0.47936]}\end{array}$ & $\begin{array}{r}0.054169 \\
(0.02039) \\
{[2.65698]}\end{array}$ & $\begin{array}{r}-0.120701 \\
(0.04299) \\
{[-2.80785]}\end{array}$ & $\begin{array}{r}-0.212583 \\
(0.06197) \\
{[-3.43053]}\end{array}$ & $\begin{array}{r}-0.067595 \\
(0.01910) \\
{[-3.53906]}\end{array}$ \\
\hline $\operatorname{DIPM}(-1)$ & $\begin{array}{r}-6.581264 \\
(4.88735) \\
{[-1.34659]}\end{array}$ & $\begin{array}{c}0.678044 \\
(4.47848) \\
{[0.15140]}\end{array}$ & $\begin{array}{c}1.040653 \\
(0.26318) \\
{[3.95408]}\end{array}$ & $\begin{array}{r}-0.074163 \\
(0.55492) \\
{[-0.13365]}\end{array}$ & $\begin{array}{r}-0.724967 \\
(0.79995) \\
{[-0.90627]}\end{array}$ & $\begin{array}{r}0.684249 \\
(0.24656) \\
{[2.77520]}\end{array}$ \\
\hline $\operatorname{DIPM}(-2)$ & $\begin{array}{r}12.55613 \\
(6.25746) \\
{[2.00658]}\end{array}$ & $\begin{array}{c}4.954525 \\
(5.73397) \\
{[0.86407]}\end{array}$ & $\begin{array}{r}-0.128647 \\
(0.33697) \\
{[-0.38178]}\end{array}$ & $\begin{array}{c}0.513376 \\
(0.71049) \\
{[0.72257]}\end{array}$ & $\begin{array}{r}-0.401089 \\
(1.02421) \\
{[-0.39161]}\end{array}$ & $\begin{array}{r}-0.230317 \\
(0.31568) \\
{[-0.72959]}\end{array}$ \\
\hline DKEMISKINAN(-1) & $\begin{array}{r}5.849513 \\
(4.92057) \\
{[1.18879]}\end{array}$ & $\begin{array}{c}1.251299 \\
(4.50892) \\
{[0.27752]}\end{array}$ & $\begin{array}{r}-0.168200 \\
(0.26497) \\
{[-0.63478]}\end{array}$ & $\begin{array}{r}1.072019 \\
(0.55869) \\
{[1.91879]}\end{array}$ & $\begin{array}{r}-0.114780 \\
(0.80539) \\
{[-0.14251]}\end{array}$ & $\begin{array}{c}0.491701 \\
(0.24823) \\
{[1.98079]}\end{array}$ \\
\hline DKEMISKINAN(-2) & $\begin{array}{c}13.83285 \\
(5.30008) \\
{[2.60993]}\end{array}$ & $\begin{array}{c}4.702449 \\
(4.85668) \\
{[0.96824]}\end{array}$ & $\begin{array}{c}0.245497 \\
(0.28541) \\
{[0.86016]}\end{array}$ & $\begin{array}{c}0.734441 \\
(0.60178) \\
{[1.22044]}\end{array}$ & $\begin{array}{r}-0.785493 \\
(0.86750) \\
{[-0.90546]}\end{array}$ & $\begin{array}{c}0.292568 \\
(0.26738) \\
{[1.09420]}\end{array}$ \\
\hline $\operatorname{DPDRB}(-1)$ & $\begin{array}{r}-2.633712 \\
(1.73702) \\
{[-1.51622]}\end{array}$ & $\begin{array}{c}1.285241 \\
(1.59170) \\
{[0.80746]}\end{array}$ & $\begin{array}{r}-0.014591 \\
(0.09354) \\
{[-0.15599]}\end{array}$ & $\begin{array}{r}0.238062 \\
(0.19723) \\
{[1.20705]}\end{array}$ & $\begin{array}{r}-0.087676 \\
(0.28431) \\
{[-0.30838]}\end{array}$ & $\begin{array}{r}0.322255 \\
(0.08763) \\
{[3.67746]}\end{array}$ \\
\hline DPDRB(-2) & $\begin{array}{r}-1.218585 \\
(1.49993) \\
{[-0.81243]}\end{array}$ & $\begin{array}{r}2.174350 \\
(1.37445) \\
{[1.58198]}\end{array}$ & $\begin{array}{r}-0.105212 \\
(0.08077) \\
{[-1.30259]}\end{array}$ & $\begin{array}{r}-0.021247 \\
(0.17031) \\
{[-0.12476]}\end{array}$ & $\begin{array}{r}-0.366096 \\
(0.24550) \\
{[-1.49119]}\end{array}$ & $\begin{array}{r}-0.200780 \\
(0.07567) \\
{[-2.65339]}\end{array}$ \\
\hline DPENGANGGURAN(-1) & $\begin{array}{r}-20.56126 \\
(6.05733) \\
{[-3.39444]}\end{array}$ & $\begin{array}{r}-7.525770 \\
(5.55058) \\
{[-1.35585]}\end{array}$ & $\begin{array}{r}-0.141704 \\
(0.32619) \\
{[-0.43442]}\end{array}$ & $\begin{array}{r}-0.857396 \\
(0.68776) \\
{[-1.24664]}\end{array}$ & $\begin{array}{r}1.333683 \\
(0.99145) \\
{[1.34519]}\end{array}$ & $\begin{array}{r}-0.016390 \\
(0.30558) \\
{[-0.05364]}\end{array}$ \\
\hline DPENGANGGURAN(-2) & $\begin{array}{r}-9.092771 \\
(5.91739) \\
{[-1.53662]}\end{array}$ & $\begin{array}{r}-1.570143 \\
(5.42234) \\
{[-0.28957]}\end{array}$ & $\begin{array}{c}0.161931 \\
(0.31865) \\
{[0.50817]}\end{array}$ & $\begin{array}{r}-0.759456 \\
(0.67188) \\
{[-1.13035]}\end{array}$ & $\begin{array}{r}0.011430 \\
(0.96854) \\
{[0.01180]}\end{array}$ & $\begin{array}{r}-0.165326 \\
(0.29852) \\
{[-0.55381]}\end{array}$ \\
\hline $\mathrm{C}$ & $\begin{array}{r}-344.9672 \\
(422.093)\end{array}$ & $\begin{array}{r}-470.7141 \\
(386.781)\end{array}$ & $\begin{array}{l}7.065728 \\
(22.7298)\end{array}$ & $\begin{array}{r}-33.86299 \\
(47.9256)\end{array}$ & $\begin{array}{l}102.2154 \\
(69.0872)\end{array}$ & $\begin{array}{r}-37.74620 \\
(21.2939)\end{array}$ \\
\hline
\end{tabular}




\begin{tabular}{|c|c|c|c|c|c|c|}
\hline & {$[-0.81728]$} & {$[-1.21700]$} & [0.31086] & {$[-0.70657]$} & [1.47951] & {$[-1.77263]$} \\
\hline R-squared & 0.864593 & 0.250748 & 0.902868 & 0.783228 & 0.692279 & 0.857174 \\
\hline Adj. R-squared & 0.779072 & -0.222463 & 0.841521 & 0.646320 & 0.497928 & 0.766968 \\
\hline Sum sq. resids & 6106.747 & 5127.714 & 17.70859 & 78.72767 & 163.6018 & 15.54190 \\
\hline S.E. equation & 17.92785 & 16.42802 & 0.965418 & 2.035574 & 2.934386 & 0.904430 \\
\hline F-statistic & 10.10979 & 0.529886 & 14.71744 & 5.720821 & 3.562012 & 9.502397 \\
\hline Log likelihood & -129.4287 & -126.6329 & -35.93906 & -59.81017 & -71.51322 & -33.85089 \\
\hline Akaike AIC & 8.901791 & 8.727056 & 3.058691 & 4.550636 & 5.282076 & 2.928180 \\
\hline Schwarz SC & 9.497246 & 9.322512 & 3.654146 & 5.146091 & 5.877532 & 3.523636 \\
\hline Mean dependent & 162.1397 & 10.62406 & 69.52000 & 19.13781 & 5.176250 & 7.237500 \\
\hline S.D. dependent & 38.14198 & 14.85823 & 2.425097 & 3.422801 & 4.141277 & 1.873558 \\
\hline \multicolumn{2}{|c|}{ Determinant resid covariance (dof adj.) } & 12370.36 & & & & \\
\hline \multicolumn{2}{|c|}{ Determinant resid covariance } & 542.0058 & & & & \\
\hline \multicolumn{2}{|l|}{ Log likelihood } & -373.1606 & & & & \\
\hline \multicolumn{2}{|l|}{ Akaike information criterion } & 28.19754 & & & & \\
\hline \multicolumn{2}{|l|}{ Schwarz criterion } & 31.77027 & & & & \\
\hline
\end{tabular}

VAR Lag Order Selection Criteria

Endogenous variables: DIHK DINFLASI DIPM DKEMISKINAN DPDRB

DPENGANGGURAN

Exogenous variables: $\mathrm{C}$

Date: 08/07/14 Time: 14:30

Sample: 19802013

Included observations: 32

\begin{tabular}{ccccccc}
\hline \hline Lag & LogL & LR & FPE & AIC & SC & HQ \\
\hline \hline 0 & -552.6660 & NA & 58790095 & 34.91662 & 35.19145 & 35.00772 \\
1 & -455.0095 & 152.5883 & 1301390. & 31.06309 & 32.98687 & 31.70077 \\
2 & -373.1606 & $97.19549^{*}$ & $95665.95^{*}$ & $28.19754^{*}$ & $31.77027^{*}$ & $29.38180^{*}$ \\
\hline \hline
\end{tabular}

* indicates lag order selected by the criterion

LR: sequential modified LR test statistic (each test at 5\% level)

FPE: Final prediction error

AIC: Akaike information criterion

SC: Schwarz information criterion

HQ: Hannan-Quinn information criterion

Dapat dilihat dari hasil out put diatas terlihat tidak terlalu banyak dan jauh perbedaan apabila kita menggunakan lag yang tidak sama. Pada kasus ini yang digunakan adalah Lag 2. Nilai R Squared nya sebesar $0.86,0.25,0.90,0.78,0.69$, dan 0.86 , dan ini menandakan terjadinya hubungan yang sangat kuat dan berkorelasi. Nilai F statisticnya juga cukup tinggi. sehingga dapat disimpulkan bahwa penggunaan Lag pada model persamaan ini tidak terlalu membawa perubahan didalam hasil akhir. Jika menggunakan metode kriteria lag length mulai dari lag 1 sampai dengan lag 2, didapat hasil probabilistic yang semua disetiap model lag disimpulkan signifikan dalam artian kecil dari alpha yang digunakan 5\%. Dapat kita lihat hasilnya untuk pemilihan uji model yang terbaik adalah pada lag 2 dengan nilai AIC dan SIA berkisar sebesar $28 \mathrm{~s} / \mathrm{d} 35$. 


\section{Hasil Uji Kointegrasi}

Date: 08/07/14 Time: 14:47

Sample (adjusted): 19822013

Included observations: 32 after adjustments

Trend assumption: Linear deterministic trend
Series:
DIHK
DINFLASI
DIPM
DKEMISKINAN
DPDRB

DPENGANGGURAN

Lags interval (in first differences): 1 to 1

Unrestricted Cointegration Rank Test (Trace)

\begin{tabular}{lllll}
\hline \hline $\begin{array}{l}\text { Hypothesized } \\
\text { No. of CE }(\mathrm{s})\end{array}$ & Eigenvalue & $\begin{array}{l}\text { Trace } \\
\text { Statistic }\end{array}$ & $\begin{array}{l}0.05 \\
\text { Critical Value }\end{array}$ & Prob.** \\
\hline \hline None ${ }^{*}$ & 0.791912 & 144.7605 & 95.75366 & 0.0000 \\
At most 1 $*$ & 0.707930 & 94.52703 & 69.81889 & 0.0002 \\
At most 2 $*$ & 0.625003 & 55.14264 & 47.85613 & 0.0089 \\
At most 3 & 0.335273 & 23.75581 & 29.79707 & 0.2109 \\
At most 4 & 0.270702 & 10.68768 & 15.49471 & 0.2314 \\
At most 5 & 0.018151 & 0.586161 & 3.841466 & 0.4439 \\
\hline \hline
\end{tabular}

Trace test indicates 3 cointegrating eqn(s) at the 0.05 level

* denotes rejection of the hypothesis at the 0.05 level

**MacKinnon-Haug-Michelis (1999) p-values

Unrestricted Cointegration Rank Test (Maximum Eigenvalue)

\begin{tabular}{lllll}
\hline \hline $\begin{array}{l}\text { Hypothesized } \\
\text { No. of CE(s) }\end{array}$ & Eigenvalue & $\begin{array}{l}\text { Max-Eigen } \\
\text { Statistic }\end{array}$ & $\begin{array}{l}0.05 \\
\text { Critical Value }\end{array}$ & Prob.** \\
\hline \hline None ${ }^{*}$ & 0.791912 & 50.23343 & 40.07757 & 0.0026 \\
At most 1 & 0.707930 & 39.38439 & 33.87687 & 0.0100 \\
At most 2* & 0.625003 & 31.38683 & 27.58434 & 0.0154 \\
At most 3 & 0.335273 & 13.06814 & 21.13162 & 0.4460 \\
At most 4 & 0.270702 & 10.10151 & 14.26460 & 0.2053 \\
At most 5 & 0.018151 & 0.586161 & 3.841466 & 0.4439 \\
\hline \hline
\end{tabular}

Max-eigenvalue test indicates 3 cointegrating eqn(s) at the 0.05 level

$*$ denotes rejection of the hypothesis at the 0.05 level

**MacKinnon-Haug-Michelis (1999) p-values

Kointegrasi suatu persamaan regersi dapat dilihat dari residualnya. Apabila residual stasioner, terdapat kointegrasi. Dari hasil output di atas dapat dilihat bahwa, nilai trace statistic $>$ critical value, begitu juga dengan nilai max eige stat $>$ critical value, ini berarti bahwa dalam jangka panjang terdapat kointegrasi di dalam model persamaan tersebut. Dalam ekonometrika variablevariable yang saling berkointegrasi dikatakan dalam kondisi keseimbangan jangka panjang atau biasa disebut long run equilibrium. Pada Uji Kointegrasi Johansen diatas menunjukan data terkointegrasi, hal ini dapat dilihat pada nilai trace dan max eigen dari kedua fungsi persamaan lebih besar dari nilai kritis pada $\alpha=0,05$. 


\section{Hasil Uji Granger Causality}

Dalam penelitian ini, uji kausalitas ini menggunakan metode Granger causality (Granger, 1969). Jika terdapat hubungan kausalitas antara variabel penelitian, maka analisis regresi (OLS) tidak dapat dilakukan karena hasil estimasinya akan bias (regresi palsu). Dalam pengujian kausalitas ini dilakukan dengan memasukkan lag berbeda. Cara ini dilakukan karena Granger causality ini sangat peka terhadap lag-lag tersebut (Gujarati, 1995).

Setelah panjang lag optimal telah ditentukan, langkah selanjutnya yaitu uji kausalitas Granger untuk mengetahui hubungan sebab-akibat antar variabel dalam penelitian. Dari hasil uji kausalitas Granger diketahui bahwa variabel PDRB mempengaruhi variabel inflasi, IHK, IPM, Kemiskinan dan Pengangguran.

Pairwise Granger Causality Tests

Date: 08/07/14 Time: 14:34

Sample: 19802013

Lags: 2

\begin{tabular}{|c|c|c|c|}
\hline Null Hypothesis: & Obs & F-Statistic & Prob. \\
\hline DINFLASI does not Granger Cause DIHK & \multirow[t]{2}{*}{32} & 1.42538 & 0.2579 \\
\hline DIHK does not Granger Cause DINFLASI & & 0.53051 & 0.5943 \\
\hline DIPM does not Granger Cause DIHK & \multirow[t]{2}{*}{32} & 2.99432 & 0.0669 \\
\hline DIHK does not Granger Cause DIPM & & 0.66678 & 0.5216 \\
\hline DKEMISKINAN does not Granger Cause DIHK & \multirow[t]{2}{*}{32} & 0.58591 & 0.5635 \\
\hline DIHK does not Granger Cause DKEMISKINAN & & 0.44550 & 0.6451 \\
\hline DPDRB does not Granger Cause DIHK & \multirow[t]{2}{*}{32} & 4.95022 & 0.0147 \\
\hline DIHK does not Granger Cause DPDRB & & 1.41113 & 0.2613 \\
\hline DPENGANGGURAN does not Granger Cause DIHK & \multirow[t]{2}{*}{32} & 5.69120 & 0.0087 \\
\hline DIHK does not Granger Cause DPENGANGGURAN & & 1.79427 & 0.1855 \\
\hline DIPM does not Granger Cause DINFLASI & \multirow[t]{2}{*}{32} & 0.12372 & 0.8841 \\
\hline DINFLASI does not Granger Cause DIPM & & 10.6108 & 0.0004 \\
\hline DKEMISKINAN does not Granger Cause DINFLASI & \multirow[t]{2}{*}{32} & 0.34729 & 0.7097 \\
\hline DINFLASI does not Granger Cause DKEMISKINAN & & 1.89624 & 0.1696 \\
\hline DPDRB does not Granger Cause DINFLASI & \multirow[t]{2}{*}{32} & 0.09524 & 0.9095 \\
\hline DINFLASI does not Granger Cause DPDRB & & 12.7785 & 0.0001 \\
\hline DPENGANGGURAN does not Granger Cause DINFLASI & \multirow[t]{2}{*}{32} & 0.90965 & 0.4147 \\
\hline DINFLASI does not Granger Cause DPENGANGGURAN & & 0.01816 & 0.9820 \\
\hline DKEMISKINAN does not Granger Cause DIPM & \multirow[t]{2}{*}{32} & 7.71483 & 0.0022 \\
\hline DIPM does not Granger Cause DKEMISKINAN & & 0.81763 & 0.4521 \\
\hline DPDRB does not Granger Cause DIPM & \multirow[t]{2}{*}{32} & 4.37552 & 0.0226 \\
\hline DIPM does not Granger Cause DPDRB & & 1.14427 & 0.3334 \\
\hline DPENGANGGURAN does not Granger Cause DIPM & \multirow[t]{2}{*}{32} & 6.03110 & 0.0068 \\
\hline DIPM does not Granger Cause DPENGANGGURAN & & 0.25317 & 0.7782 \\
\hline
\end{tabular}




\begin{tabular}{lccc}
\hline \hline DPDRB does not Granger Cause DKEMISKINAN & \multirow{2}{*}{32} & 0.17953 & 0.8367 \\
DKEMISKINAN does not Granger Cause DPDRB & & 1.21390 & 0.3127 \\
\hline \hline DPENGANGGURAN does not Granger Cause DKEMISKINAN & \multirow{2}{*}{32} & 1.20910 & 0.3141 \\
DKEMISKINAN does not Granger Cause DPENGANGGURAN & & 1.57263 & 0.2259 \\
\hline \hline DPENGANGGURAN does not Granger Cause DPDRB & \multirow{2}{*}{32} & 0.51339 & 0.6042 \\
DPDRB does not Granger Cause DPENGANGGURAN & & 4.63624 & 0.0186 \\
\hline \hline
\end{tabular}

Dari hasil uji causality dapat diketahui bahwa hampir semua variable berkausalitas, tetapi hanya mempunyai hubungan satu arah tidak dua arah, serta sebagian lagi tidak, dan signifikan dengan tingkat alpha 5\% untuk sebagian hubungan satu arah. Ini menunjukkan bahwa data ini layak untuk digunakan dalam uji VECM. Dari uji tersebut juga diketahui hanya ada beberapa komponen yang tidak menunjukkan hasil probabilitas yang menunjukan kurang signifikan.

\section{Estimasi Persamaan Jangka Panjang (Error Correction Model/ECM)}

Prinsip yang mendasari kointegrasi adalah adanya hubungan keseimbangan jangka panjang dari data time series. Model persamaan ECM merupakan model persamaan dinamis dalam jangka pendek. Karena dalam jangka pendek variabel-variabel dalam model tidak ekuilibrium. Dari data time series yang saling terintegrasi perlu dilihat lebih lanjut apakah salah satu variabel mempengaruhi variabel lainnya atau sebaliknya. Proses untuk mengetahui keadaan tersebut dapat digunakan ECM. Dalam penelitian ini pengujian ECM dilakukan dalam periode data tahun 1980-2013, sebagai berikut:

Dependent Variable: DPDRB

Method: Least Squares

Date: 08/07/14 Time: 15:00

Sample: 19802013

Included observations: 34

\begin{tabular}{lllll}
\hline \hline Variable & Coefficient & Std. Error & t-Statistic & Prob. \\
\hline \hline DIHK & -0.021131 & 0.020674 & -1.022089 & 0.3155 \\
DINFLASI & -0.147113 & 0.046640 & -3.154204 & 0.0038 \\
DIPM & -0.709956 & 0.537158 & -1.321690 & 0.1970 \\
DKEMISKINAN & -0.415440 & 0.611290 & -0.679612 & 0.5023 \\
DPENGANGGURAN & 0.523289 & 0.700683 & 0.746828 & 0.4614 \\
C & 63.70866 & 42.49768 & 1.499109 & 0.1450 \\
\hline \hline R-squared & 0.418241 & Mean dependent var & 5.339118 \\
Adjusted R-squared & 0.314356 & S.D. dependent var & 4.071735 \\
S.E. of regression & 3.371544 & Akaike info criterion & 5.427404 \\
Sum squared resid & 318.2847 & Schwarz criterion & 5.696762 \\
Log likelihood & -86.26587 & Hannan-Quinn criter. & 5.519263 \\
F-statistic & 4.025987 & Durbin-Watson stat & 2.367719 \\
Prob(F-statistic) & 0.007054 & & \\
\hline \hline
\end{tabular}


Dari hasil uji tersebut diketahui bahwa nilai F-statistic sebesar 0.007054 lebih kecil dari alpha (0.05) artinya bahwa semua variabel independen secara simultan memiliki pengaruh terhadap variabel dependen (PDRB) dalam jangka pendek. Variabel independen yang paling dominan berpengaruh terhadap PDRB dalam jangka pendek ialah variabel inflasi. Terbukti bahwa data dalam penelitian ini terkointegrasi atau memiliki hubungan atau keseimbangan jangka panjang, sangat mungkin semua variable dalam data terjadi ketidakseimbangan atau variable-variable datanya tidak mencapai keseimbangan, ini juga dapat disebut dengan kesalahan kesimbangan. Ini dapat kita lihat nilai Ut signifikan pada tingkat alpha 5\% terlihat variable inflasi sangat signifikan, ini berarti tidak ada kesalahan keseimbangan, antar variable saling mempengaruhi, kesemua variable saling menyesuaikan. Persamaan model PDRB dapat ditulis sebagi berikut:

$\mathrm{Y}(\mathrm{DPDRB})=63.70866-0.021131 \mathrm{X}_{1 \mathrm{t}}(\mathrm{DIHK})-0.147113 \mathrm{X}_{2 \mathrm{t}}(\mathrm{DINFLASI})-0.709956 \mathrm{X}_{3 \mathrm{t}}(\mathrm{DIPM})-$ $0.415440 \mathrm{X}_{4 \mathrm{t}}\left(\right.$ KEMISKINAN) $+0.523289 \mathrm{X}_{5 \mathrm{t}}($ PENGANGGURAN)

\section{Estimasi Persamaan Jangka Pendek}

Selanjutnya, pada teori mengenai ECM sebelumnya telah dijelaskan bahwa kointegrasi suatu persamaan regersi dapat dilihat dari residualnya. Apabila residual stasioner, terdapat kointegrasi. Pada workfile ECM ada variabel dengan nama resid, yang merupakan tempat menyimpan residual persamaan yang baru saja diestimasi, sehingga nilainya berubah-ubah. Padahal residual persamaan jangka panjang, akan diuji stasioneritasnya dan digunakan sebagai variabel pada persamaan berikutnya. Oleh karena itu, langsung setelah estimasi persamaan jangka panjang, harus menyimpa residual dalam bentuk variabel baru yang tetap. Caranya adalah meng-generate variabel baru yg nilainya sama dengan variabel resid. Misal membuat variabel baru tersebut dengan nama res. Variabel res selanjutnya diuji kembali stasioneritasnya, hasilnya sebagia berikut.

Null Hypothesis: RES has a unit root

Exogenous: Constant, Linear Trend

Lag Length: 0 (Automatic - based on SIC, maxlag=8)

\begin{tabular}{llll}
\hline \hline & & t-Statistic & Prob.* \\
\hline \hline Augmented Dickey-Fuller test statistic & -6.613625 & 0.0000 \\
\hline Test critical values: & $1 \%$ level & -4.262735 & \\
& $5 \%$ level & -3.552973 & \\
& $10 \%$ level & -3.209642 & \\
\hline \hline
\end{tabular}

*MacKinnon (1996) one-sided p-values. 
Augmented Dickey-Fuller Test Equation

Dependent Variable: D(RES)

Method: Least Squares

Date: 08/07/14 Time: 15:10

Sample (adjusted): 19812013

Included observations: 33 after adjustments

\begin{tabular}{lllll}
\hline \hline Variable & Coefficient & Std. Error & t-Statistic & Prob. \\
\hline \hline RES(-1) & -1.189696 & 0.179886 & -6.613625 & 0.0000 \\
C & -0.064411 & 1.138564 & -0.056572 & 0.9553 \\
@TREND(1980) & 0.002034 & 0.058447 & 0.034793 & 0.9725 \\
\hline \hline R-squared & 0.593424 & Mean dependent var & 0.025511 \\
Adjusted R-squared & 0.566319 & S.D. dependent var & 4.852793 \\
S.E. of regression & 3.195779 & Akaike info criterion & 5.248047 \\
Sum squared resid & 306.3902 & Schwarz criterion & 5.384093 \\
Log likelihood & -83.59278 & Hannan-Quinn criter. & 5.293822 \\
F-statistic & 21.89351 & Durbin-Watson stat & 2.053506 \\
Prob(F-statistic) & 0.000001 & & & \\
\hline \hline
\end{tabular}

Hasil Output uji di atas memberikan bukti bahwa variabel res stasioner pada derajat Level, dan secara tersirat menyatakan bahwa PDRB, IHK, INFLASI, IPM, KEMISKINAN dan PENGANGGURAN saling berkointegrasi.

Model berikutnya adalah VECM dimana semua variable pada data diasumsikan bersifat stationer. Berikut hasil uji untuk model Vector Error Correction Model (VECM).

Dependent Variable: DPDRB

Method: Least Squares

Date: 08/07/14 Time: 15:19

Sample (adjusted): 19812013

Included observations: 33 after adjustments

\begin{tabular}{llccc}
\hline \hline Variable & Coefficient & Std. Error & t-Statistic & Prob. \\
\hline \hline DIHK & -0.020764 & 0.020967 & -0.990310 & 0.3311 \\
DINFLASI & -0.137756 & 0.048090 & -2.864522 & 0.0082 \\
DIPM & -0.873165 & 0.593927 & -1.470155 & 0.1535 \\
DKEMISKINAN & -0.625917 & 0.664588 & -0.941813 & 0.3550 \\
DPENGANGGURAN & 0.839574 & 0.786729 & 1.067171 & 0.2957 \\
RES(-1) & -0.236787 & 0.217373 & -1.089309 & 0.2860 \\
C & 76.60662 & 46.92985 & 1.632364 & 0.1147 \\
\hline \hline R-squared & 0.432828 & Mean dependent var & 5.238485 \\
Adjusted R-squared & 0.301942 & S.D. dependent var & 4.091704 \\
S.E. of regression & 3.418615 & Akaike info criterion & 5.482179 \\
Sum squared resid & 303.8601 & Schwarz criterion & 5.799620 \\
Log likelihood & -83.45596 & Hannan-Quinn criter. & 5.588988 \\
F-statistic & 3.306906 & Durbin-Watson stat & 2.100402 \\
Prob(F-statistic) & 0.014879 & & & \\
\hline \hline
\end{tabular}


Untuk persamaan jangka pendek, pastikan nilai probabilitas F-statistic berada di bawah alpha (0.05). Setelah itu, cek speed of adjustment-nya (koefisien dari res(-1)). Nilai koefisien tersebut harus negatif dan signifikan (probabilitasnya berada di bawah 0.05). Kemudian kita cek probabilitas masing-masing variabel, mana saja yang memiliki nilai signifikan atau berada di bawah alpha (0.05). dari hasil uji tersebut terlihat bahwa nilai probabilistic (F-Statistic) signifikan sebesar $0.014879<0.05$ dan nilai speed of adjustment (koefisien res-1) sebesar -0.236787 namun tidak signifikan. Out put diatas juga memberikan informasi bahwa perubahan jangka panjang untuk variable keseluruhan mempunyai dampak positif pada perubahan jangka pendek. Dalam jangka pendek variabel inflasi juga berpengaruh paling signifikan. Berdasarkan output persamaan jangka pendek, diperoleh persamaan sebagai berikut:

$\mathrm{Y}(\mathrm{DPDRB})=76.6066-0.020764 \mathrm{X}_{1 \mathrm{t}}(\mathrm{DIHK})-0.137756 \mathrm{X}_{2} \mathrm{t}($ DINFLASI $)-0.873165 \mathrm{X}_{3 \mathrm{t}}(\mathrm{DIPM})-$ $0.625917 \mathrm{X}_{4 \mathrm{t}} \quad($ KEMISKINAN $)+0.839574 \mathrm{X}_{5 \mathrm{t}}($ PENGANGGURAN)

\section{KESIMPULAN}

Setelah melakukan analisis dan pembahasan terhadap hasil penelitian maka dapat disimpulkan bahwa dalam jangka pendek variabel inflasi berpengaruh singifikan terhadap PDRB, tetapi variabel independen lainnya yaitu IHK, IPM, Kemiskinan dan Pengangguran berpengaruh tidak signifikan. Dilihat dari nilai R-squared dalam uji ECM sebesar 0.432828 artinya bahwa 43.28\% PDRB dipengaruhi oleh variabel independen yang diteliti dan sisanya dipengaruhi variabel lain yang tidak dieliti dalam penelitian ini dan apapbila dilihat dari nilai Probabilitas (F-statistic) sebesar $0.014879(<\alpha=5 \%)$ yang berarti secara simultan variabel independen memiliki pengaruh signifikan terhadap PDRB dalam jangka pendek. Berdasarkan nilai koefisien masing-masing variabel dapat disimpulkan bahwa jika dalam jangka pendek nilai inflasi mengalami perubahan sebesar 1 persen maka PDRB akan mengalami perubahan sebesar 0.14\% dengan arah perubahan yang tidak searah dengan perubahan inflasi. Sedangkan IHK, IPM, Kemiskinan, dan Pengangguran akan mengalami perubahan sebesar 0.02\%,0.87\%, 0.62\%, dan $0.83 \%$ dengan arah perubahan yang berlawanan dengan perubahan PDRB kecuali variabel pengangguran searah dengan perubahan PDRB. Berdasarkan hasil perhitungan koefisien jangka panjang dari persamaan ECM, dapat disimpulkan bahwa dalam jangka panjang setiap perubahan inflasi sebesar 1 persen akan mengakibatkan perubahan pada PDRB sebesar 0.15\% dengan arah perubahan berlawanan dengan perubahan inflasi. Demikian juga dengan variabel IHK, IPM, Kemiskinan dan Pengangguran, setiap perubahan 1\% setiap variabel tersebut dalam jangka panjang akan mengakibatkan perubahan sebesar $0.02 \%, 0.7 \%, 0.42 \%$ dan $0.52 \%$ pada PDRB di Sumatera Selatan dengan arah perubahan yang juga berlawanan dengan perubahan variabelvariabel tersebut kecuali variabel pengangguran searah dengan perubahan PDRB. Jika dilihat dari nilai probabilistik (F-statistic) sebesar 0.007054 artinya bahwa secara simultan semua variabel independen memiliki pengaruh yang signifikan terhadap PDRB. Berdasarkan hasil 
estimasi, dapat disimpulkan pula bahwa variabel bebas yang mempunyai pengaruh paling dominan terhadap PDRB ialah inflasi, dimana dalam jangka pendek maupun jangka panjang memiliki pengaruh yang paling dominan.

\section{REFERENSI}

Ardiyanto, Danis. 2012. Analisa Keterkaitan Pengeluaran Pemerintah dan Produk Domesik Bruto di Indonesia: Pendekatan Vector Error Correction Model (VECM). Fakultas Ekonomi dan Bisnis Universitas Brawijaya Malang.

Badan Pusat Statistik Provinsi Sumatera Selatan. 2014. Palembang: BPS

Badan Pusat Statistik. 2000. Penduduk Indonesia Hasil Sensus Penduduk 2000. Buku I. Jakarta: BPS.

Badan Pusat Statistik Indonesia. 2014. Jakarta: BPS

BPS-Bappenas-UNDP, 2001. Indonesia Human Development Report 2001. Towards a New Consensus: Democracy and Human Development in Indonesia. Jakarta: BPS-Statistics Indonesia, Bappenas dan UNDP Indonesia.

Badan Perencanaan Pembangunan Daerah Provinsi Sumatera Selatan. 2013

Cahyat. 2004. Bagaimana Kemiskinan Diukur? Beberapa Model Penghitungan Kemiskinan di Indonesia. Governance Brief, 21-8.

Chalik Marwadi, Muhammad. 2011. Tutorial Eviews: Error Correction Mechanism (ECM):http://statistikceria.blogspot.com/2014/02/error-correction-mechanismecm.html

Enders, Walter. 2004. Applied Econometrics Time Series (2rd ed). New York: Wiley.

Engle, RF and C.W.J Granger. 1987. Cointegration and Error Correction Representation, Estimation and Testing. Econometrica.

Greene, Wlliam H. 2003. Econometric Analysis (5th ed). New York: Prentice Hall.

Gujarati, Damodar N.2004. Basic Econometrics. New York: The McGraw-Hill Companies.

Gujarati, Damodar. 1995. Basic Econometrics. 3th Ed. Jakarta. Erlangga.

Mankiw, Gregory. 2006. Makroekonomi Edisi Keenam. Jakarta: Penerbit Erlangga.

Nanga, Muana. 2005. Makroekonomi: Teori, Masalah dan Kebijakan. Edisi Kedua. Jakarta: PT. Raja Grafika Persada.

Subagyo, Ahmad. 2009. Analisis ECM dan VECM pada Variabel Makro Ekonomi di Indonesia. Wawasan Tridharma: Majalah Ilmiah Kopertis Wilayah IV Nomor 01 Tahun XXVI, Agustus 2013 ; STT No.2009/SK/DITJEN PPG/STT/1994 ; ISSN 0215-8256.

Prasetiono, Dwi Wahyu. 2010. Analisis Pengaruh Faktor Fundamental Ekonomi Makro dan Harga Minyak Terhadap Saham LQ45 Dalam Jangka Pendek dan Jangka Panjang. Journal of Indonesian Applied Economics Vol. 4 No. 1 Mei 2010, 11-25.

Soekanto, Soerjono. Sosiologi Suatu Pengantar. PT Raja Grafindo Persada, Jakarta 2006.

Statistik Bank Indonesia. 2014. Jakarta 
Sukirno, Sadono. 2004. Makro Ekonomi. Edisi Ketiga. Jakarta: PT. Raja Grafindo Persada.

United Nation Development Program.1995. Human Development Report 1995. New York: Oxford University Press.

http://nhuehayati.students.uii.ac.id/2014/03/31/indeks-harga-konsumen-ihk-\%E2\%80\%93consumer-price-indeks-cpi/ 